principles herein involved. The method is merely the application of well-known facts to economic ends.-Albert F. Woods, Division of Vegetable Physiology and Pathology, United States Department of Agriculture.

\title{
A CASE OF ECBLASTESIS AND AXIAL PROLIFICATION IN LEPIDIUM APETALUM.
}

(WITH PLATE IX)

THE teratological specimen of Lepidium described below was collected by Mr. F. S. Collins at Malden, Mass., in August. Noting its remarkable character Mr. Collins has kindly referred it to the writer for examination. The plant is about $4^{\mathrm{dm}}$ high, much branched, and already destitute of its lower leaves, so that it lacks some of the most characteristic features for specific identification. However, the cotyledons are distinctly incumbent, as shown in fig. 12, and the terminal racemes, which have normal fruit, show the orbicular pods and approximate regularly spreading pedicels characteristic of L. apetalum Willd., to which the plant is confidently referred. Most of the flowers show no sign of petals whatever, while in others there are rudimentary petals, as shown in fig. II. These, however, have been found in normal specimens of L. apetalum, and therefore raise no appreciable doubt as to the identification. As mentioned above, the terminal racemes of the main axis and of several of the branches are entirely normal in their appearance. On the other hand, the numerous lateral racemes are all greatly modified. They are much looser, and the slender pedicels spread at various angles, instead of being regularly divaricate as in the normal racemes; but what is more conspicuous is the modification of the fruit from an orbicular pod to a long clavate or pear shaped body, which is not sessile in the calyx, but borne upon a filiform ascending stipe, in some cases nearly equaling the pedicels of the flowers.

The microscopic examination of one of these racemes shows a series of teratological modifications of the floral organs. Some of these changes are good examples of well recognized teratological phenomena, namely, ecblastesis and axial prolification, while others are too irregular for any very satisfactory classification or morphological interpretation. A cursory search in literature for records of similar monstrosities in the genus Lepidium has disclosed only a single mention of such 
phenomena, namely, by Mr. Masters, who in his Vegetable Teratology, p. 148 , gives Lepidium in a rather long list of genera, in which axillary prolification has been noted. However, this mention is accompanied by no details whatever, except that the prolification arose from the axils of the petals and stamens, while even the species is not stated upon which the observation had been made. The present case seems therefore worthy of record.

Unfortunately here, as in many cases of monstrosities, it is the mature plant and not its developmental stage which is known to us. Although it is possible to trace the varying malformations in the successive flowers of a given centripetal inflorescence, it is quite impossible to assume that the upper flowers represent the early stages through which the lower ones have passed, for often the modifications are very different in kind. However, in the absence of what might pass as developmental series, there is no better method open than to describe the successive flowers of a raceme, beginning at the lowest where the members are fully grown. The lowest flower in one of the teratological racemes is shown in $f i g .1$. From $a$, the axis of the raceme, the pedicel $(b)$ diverges at a considerable angle and bears, at about the usual distance from the axis, the 4 -membered calyx $(c)$. Opposite the dorsal and ventral sepals are borne two stamens, each doubtless representing a pair of the longer stamens in the theoretical tetradynamous andrœcium. Of the lateral sepals one is empty, and the other bears in its axil a very rudimentary flower $(e)$, which, itself scarcely larger than a stamen, is slender-pedicelled and possesses rudiments of three sepals, two stamens, and an ovary. This is, of course, a clear case of ecblastesis or budding from the axil of a floral member, for it is quite impossible to regard this little flower, with its clearly marked phyllome and caulome, as any modification of a stamen or petal.

From the center of the main flower, and quite continuous with its axis, springs what is evidently a stipitate elongated gynœcium $(f)$ of somewhat irregular clavate form, bearing at the tip a small stigma, and showing upon the surfaces indication of the limits of the two carpels. Fig. 2 represents the gynœcium with one valve removed. An ovule is borne upon each side, further demonstrating the gynœecial nature of the organ, and at the base of the capsule may be seen a very rudimentary flower, similar to the one borne in the axil of the sepal below, except that its diminutive calyx appears to have only two sepals instead of three. As this little flower is borne within and at the very base of 
the gynœcium, it would seem to be a clear case of axial prolongation and prolification.

Fig. 3 represents a very similar case of prolification. Here, however, the main flower has four sepals and two stamens, without any sign of ecblastesis, while the gynœcium has undergone further development, the walls of the capsule being split down one suture, notched at the other, and thrown back as a sort of spathe-like envelope, from which emerges the here further developed axial prolification in the shape of a distinctly formed little trisepalous and diandrous flower $(e)$. Its little ovary is borne upon a distinct stipe, which suggests the beginning of still further prolification. A careful examination has failed to reveal any traces of ovules or funiculi on the spathe-like organ $(d)$. However, its analogy to the similar and ovuliferous structure shown in fig. $I$ is too close to leave any doubt as to its gynœcial nature. Fig. 4 shows another flower higher in the raceme and of similar but less developed structure. The bases of two stamens were found within the calyx $(a)$, and the interior of the gynœcium $(b)$ is shown in fig. 5 (where it has been divided through the middle of the valves). The placenta, which, from the way the ovary was divided, here appears as a median line, bears a single ovule, while at the base is a rudimentary flower similar to that shown in fig. 2 .

A little higher upon the raceme occurred the proliferous flower shown in fig. 6. It has only two sepals, the dorsal and ventral $(a)$, and one stamen $(b)$ borne opposite the ventral sepal. The central axis was then prolonged and a second disepalous calyx $(c)$ borne above. In the axils of each of these sepals were borne rudimentary flowers $(d)$, and springing laterally from the axis at nearly the same height were three stamens. Only two of these can be shown in the figure, the third being concealed by the axis. The morphology of this flower is capable of various interpretations, and in its mature state the precise relation of the stamens to the sepals could not be satisfactorily made out; especially as the stamens were of an odd number. However, it seems likely that here the lateral sepals have been developed, and the dorsoventral pair suppressed, while the longer pairs of stamens of the theoretical tetradynamous andrœcium are represented on one side by a single stamen, on the other by a pair. The structure of the minute flowers $(a)$ was essentially as those described above, one of which is represented in fig. $I, e$. The main axis was then produced by another distinct internode and bore another disepalous flower $(e)$ which con- 
tained two stamens, opposite the sepals (here doubtless the dorsoventral pair), and in the middle a minute and obscure rudiment of still another flower $(f)$. In the whole axis we have thus a case of triple prolification, together with distinct ecblastesis from each sepal of the middle pair.

The upper flowers of the raceme, which we have been following, although modified in various degrees, showed a greater and greater simplicity of structure, as will be seen from the three represented in figs. 7, 8, and 9. The last shows the simplest form of flower observed. Its envelope consisted of two sepals with which alternated two obscure microscopic rudiments, doubtless the inner sepals. The andrœcium was formed of two stamens opposite the developed sepals, and the gynœcium of two carpels of normal position. Fig. IO shows a diagram of the flower. For the sake of comparison the normal flower from one of the terminal racemes of the same plant is shown in fig. 11 . In this the minute rudiments of petals may be seen alternating with the sepals, and one of the two stamens is just visible protruding from behind the ventral sepal. The sessile normal capsule of orbicular contour of course presents a striking contrast to the deformed stipitate gynœcium of the modified flowers. The specimen shows an apparently sound and normal root and in general shows no cause for deformities described. The plant is preserved in the Herbarium of the Middlesex Institute at Malden, Mass.-B. L. RoBinson, Harvard University. 


\section{$2 \mathrm{BHL}$ Biodiversity Heritage Library}

Robinson, B L. 1897. "A Case of Ecblastesis and Axial Prolification in Lepidium apetalum." Botanical gazette 24(3), 209-212. https://doi.org/10.1086/327583.

View This Item Online: https://www.biodiversitylibrary.org/item/94398

DOI: https://doi.org/10.1086/327583

Permalink: https://www.biodiversitylibrary.org/partpdf/222798

\section{Holding Institution}

Missouri Botanical Garden, Peter H. Raven Library

\section{Sponsored by}

Missouri Botanical Garden

\section{Copyright \& Reuse}

Copyright Status: Public domain. The BHL considers that this work is no longer under copyright protection.

This document was created from content at the Biodiversity Heritage Library, the world's largest open access digital library for biodiversity literature and archives. Visit BHL at https://www.biodiversitylibrary.org. 